\title{
O CONTROLE (NÃO)CONSENSUAL DOS ACORDOS FIRMADOS NA FASE INQUISITÓRIA E PREPARATÓRIA À AÇÃO DE IMPROBIDADE ADMINISTRATIVA
}

Flávia Baracho Lotti Campos de Souza ${ }^{*}$

\section{RESUMO}

$\mathrm{O}$ art. $17, \S 1^{\circ}$ da Lei n. $^{\circ} 8.429 / 92$, alterado pela Lei n. $^{\circ} 13.964 / 19$, passou a admitir a celebração de acordos de não persecução cível nas ações de improbidade administrativa, validando prática do Ministério Público. Quando celebrado durante o inquérito civil poderá impor ao investigado as sanções da Lei, dispensada a homologação judicial. Assim, a partir de uma pesquisa bibliográfica, utilizando-se do método dedutivo e referencial teórico a consensualidade e as formas de controle da Administração Pública de Luciano Ferraz, buscarse-á demonstrar que inexiste consensualidade nos ajustes realizados na fase inquisitória, quando dispensado o contraditório e a ampla defesa ao investigado.

PALAVRAS-CHAVE: Improbidade administrativa; Acordos; Controle da Administração; Consensualidade; Inquérito civil.

\section{THE (NON)CONSENSUAL CONTROL OF SIGNED AGREEMENTS IN INQUISITORY AND PREPARATORY PHASE OF ADMINISTRATIVE MISCONDUCT ACTION}

\begin{abstract}
The art. $17, \S 1^{\circ}$ of Act $n . .^{\circ} 8.429 / 92$, amended by Act n. ${ }^{\circ} 13.964 / 19$, began to admit conclusion of non-civil pursuit agreements in administrative misconduct actions, validating practice of Public Prosecutor's Office. When concluded during civil investigation, it may impose on the investigated the sanctions of Act, dispensing judicial approval. Thus, from a bibliographical research, using deductive method and theoretical framework the consensually and forms of control of Public Administration of Luciano Ferraz, it will be sought to demonstrate that there is no consensus in adjustments made in inquisitive phase, when dispensed the contradictory and the broad defense to the investigated.
\end{abstract}

KEYWORDS: Administrative misconduct; Agreements; Administration Control; Consensually; Civil inquiry.

\section{INTRODUÇÃO}

\footnotetext{
* Mestranda em Direito pela Universidade FUMEC. Pós-graduada em Direito Processual pela Pontifícia Universidade Católica de Minas Gerais (PUC MINAS). Assessora Judiciária no Tribunal de Justiça do Estado de Minas Gerais (TJMG). E-mail: flaviabaracho@gmail.com. Currículo Lattes: http://lattes.cnpq.br/6974995901549094.
} 
A possibilidade de celebração de acordos nas ações cíveis de improbidade administrativa era expressamente proibida pela Lei 8.429/92 - Lei de Improbidade Administrativa (BRASIL, 1992), em descompasso à reforma processual de 2015 que elevou os acordos, a conciliação e a busca por outros meios de solução consensual de conflitos como fundamento da nova ordem processual brasileira (BRASIL, 2015).

Nos termos do art. $17, \S 1^{\circ}$ da Lei n. $^{\circ} 8.429 / 92$, em sua redação original, vedava-se a transação, o acordo ou a conciliação no curso das ações de improbidade, em razão do princípio da indisponibilidade do interesse público (BRASIL, 1992).

Com o advento da Lei n. ${ }^{\circ}$ 13.964/19 - Pacote Anticrime, que aperfeiçoou a legislação penal e processual penal, dentre outras disposições, o art. $17, \S^{\circ}$ da Lei n. ${ }^{\circ}$ 8.429/92 foi alterado para permitir a celebração de acordos de não persecução cível nas ações de improbidade administrativa de que trata a Lei (BRASIL, 2019). A possibilidade de realizálo, contudo, limita-se à fase do inquérito civil ou procedimento preparatório administrativo, não se estendendo ao procedimento principal.

Essa é a conclusão que se extrai da interpretação dos artigos legais, em conjunto com as justificativas aos vetos realizados pelo Presidente da República do Brasil a outros artigos que compunham o Projeto de Lei do Pacote Anticrime.

Ocorre que durante o inquérito civil, por se tratar de uma fase investigatória, em tese, sem qualquer imposição sancionatória, comumente é dispensado o contraditório e a ampla defesa.

Não obstante, no caso dos ajustes firmados com base na Resolução do Conselho Nacional do Ministério Público n. ${ }^{\circ}$ 179/17 e, dentro do Estado de Minas Gerias, com base na Resolução do Conselho Superior do Ministério Público do Estado de Minas Gerais n. ${ }^{\circ}$ 03/17, mesmo na fase inquisitória, ao acusado poderá ser aplicado qualquer das sanções previstas na Lei de Improbidade Administrativa, bastando a homologação pelo Conselho Superior do Ministério Público (BRASIL, 2017; MINAS GERAIS, 2017).

Além disso, segundo Luciano Ferraz, os termos de ajustamento de conduta são considerados instrumentos de controle consensual da administração pública, em substituição ao controle sancionador ou repressivo, eis que a pacificação das controvérsias ocorre de forma negociada e não impositiva, tal como na ação de improbidade administrativa (FERRAZ, 2019). 
Contudo, pergunta-se: o que há de consensual nos termos de ajustamento de conduta realizados durante o inquérito civil?

Este artigo tem, pois, como propósito, a partir de uma pesquisa bibliográfica, utilizando-se o método dedutivo e como referencial teórico a consensualidade e as formas de controle da Administração Pública de Luciano Ferraz (FERRAZ, 2019), demonstrar que inexiste consensualidade nos ajustes realizados na fase inquisitória das ações de improbidade administrativa, quando dispensado o contraditório e a ampla defesa ao investigado.

Para tanto, o artigo será estruturado de forma a apresentar a evolução normativa dos acordos nas ações de improbidade administrativa, com as alterações promovidas pelo Pacote Anticrime, bem como as diretrizes traçadas na Resolução n. ${ }^{\circ}$ 179/17 do Conselho Nacional do Ministério Público e na Resolução n. ${ }^{\circ}$ 03/17 do Conselho Superior do Ministério Público do Estado de Minas Gerais n. ${ }^{\circ}$ 03/17 e discorrer, a partir da doutrina de Luciano Ferraz, sobre o controle consensual da Administração Pública para, ao final, concluir pela inexistência de consensualidade nos acordos firmados na fase inquisitória e preparatória à ação de improbidade administrativa, se não garantido ao investigado o direito ao contraditório e à ampla defesa.

\section{A EVOLUÇÃO NORMATIVA DOS ACORDOS NAS AÇÕES DE IMPROBIDADE ADMINISTRATIVA}

As ações de improbidade administrativa, instrumento processual civil de persecução aos atos ímprobos praticados na Administração Pública, instituídas com a entrada em vigor da Lei n. ${ }^{\circ}$ 8.429/92 - Lei de Improbidade Administrativa (BRASIL, 1992) trouxe grande avanço na ordem processual brasileira no combate à corrupção.

Desde a Constituição Republicana de 1981 havia uma preocupação e cuidado com o trato da coisa pública, imputando-se ao Presidente da República o crime de responsabilidade em razão de atos que atentassem contra a probidade administrativa (MACHADO, 2017, p. 56).

Foi no período pós-redemocratização com a Constituição de 1988 que a responsabilização pela prática de atos de improbidade se estendeu a todos os agentes públicos, nos termos do art. $37, \S 4^{\circ}$ da CR/88 (BRASIL, 1988), num verdadeiro controle do Poder 
Administrativo, tornando-se direito fundamental do cidadão a boa administração e a condução responsável dos assuntos do Estado pelo governo (MOTTA, 2012, p. 152).

\footnotetext{
Art. 37. A administração pública direta e indireta de qualquer dos Poderes da União, dos Estados, do Distrito Federal e dos Municípios obedecerá aos princípios de legalidade, impessoalidade, moralidade, publicidade e eficiência e, também, ao seguinte:

$[\ldots]$

$\S 4^{\circ}$ Os atos de improbidade administrativa importarão a suspensão dos direitos políticos, a perda da função pública, a indisponibilidade dos bens e o ressarcimento ao erário, na forma e gradação previstas em lei, sem prejuízo da ação penal cabível. (BRASIL, 1988)
}

A Lei n. ${ }^{\circ} 8.429 / 92$ deu efetividade à norma constitucional e definiu, dentre outras disposições, quais seriam os atos ímprobos, suas sanções e o procedimento administrativo e judicial cabível na apuração e responsabilização civil dos sujeitos ativos da improbidade (BRASIL, 1992).

$\mathrm{O}$ art. $17, \S 1^{\circ}$ da Lei, em sua redação original, proibia a transação, o acordo ou a conciliação nas ações de que se tratava a Lei, cujo fundamento pautava-se, basicamente, na indisponibilidade do interesse público (DI PIETRO, 2019, p. 1832), caracterizada pela busca na preservação do patrimônio público e da moralidade administrativa.

Ao administrador era, portanto, vedado acordar com o investigado ou réu na ação de improbidade administrativa, pois, o interesse público é de titularidade da coletividade e não da pessoa física ou jurídica em particular.

Ocorre que os princípios da supremacia e o da indisponibilidade do interesse público foram ganhando novos contornos e interpretações no âmbito do Direito Administrativo.

Deixaram de ser encarados como princípios absolutos, para que sejam aplicados de forma ponderada, conforme o caso concreto, utilizando-se dos postulados da proporcionalidade e da razoabilidade, de forma a assegurar o núcleo essencial dos direitos fundamentais (NOHARA, 2010, p.124).

Bem por isso Odete Medauar já defendia a possibilidade de realização de acordos pela Administração, já que “o interesse público se realiza plenamente, sem ter sido deixado de lado, na rápida solução de controvérsias, na conciliação de interesses, na adesão de particulares às suas diretrizes, sem os ônus e a lentidão da via jurisdicional." (MEDAUAR, 2018, p. 129). 
Nesta seara, vários instrumentos consensuais de conflitos surgiram como meio eficazes no combate à corrupção, tais como a delação premiada ${ }^{1}$ e o acordo de leniência ${ }^{2}$, inclusive em hipóteses passíveis de repressão civil pelas ações de improbidade administrativa. Igualmente o Conselho Nacional do Ministério Público - CNMP e o Conselho Superior do Ministério Público do Estado de Minas Gerais - CSMPMG firmaram resoluções recomendando e orientando seus membros à realização de acordos nas hipóteses de improbidade administrativa.

\subsection{OS COMPROMISSOS DE AJUSTAMENTO DE CONDUTA NAS RESOLUÇÕES DO CNMP E CSMPMG DO ESTADO DE MINAS GERAIS}

Com o objetivo de promover a justiça e de reduzir os litígios, bem como garantir a efetividade dos compromissos de ajustamento de conduta, realizados no âmbito dos inquéritos civis e nas ações civis públicas, o Conselho Nacional do Ministério Público -CNMP editou a Resolução n. ${ }^{\circ} 179$ de 26 de julho de 2017 que, dentre outras coisas, estipulou:

\footnotetext{
Art. $1^{\circ}$. O compromisso de ajustamento de conduta é instrumento de garantia dos direitos e interesses difusos e coletivos, individuais homogêneos e outros direitos de cuja defesa está incumbido o Ministério Público, com natureza de negócio jurídico que tem por finalidade a adequação da conduta às exigências legais e constitucionais, com eficácia de título executivo extrajudicial a partir da celebração. $[\ldots]$

$\S 2^{\circ}$ É cabível compromisso de ajustamento de conduta nas hipóteses configuradoras de improbidade administrativa, sem prejuízo do ressarcimento ao erário e da aplicação de uma ou algumas das sanções previstas em lei, de acordo com a conduta ou o ato praticado." (BRASIL, 2017).
}

O compromisso de ajustamento de conduta, previsto na Lei 7.347/85 - Lei de Ação Civil Pública, foi estendido às ações de improbidade administrativa, considerada majoritariamente uma espécie de ação civil pública. Apesar de dispor de procedimento próprio e específico, em última análise, tutela os interesses difusos e coletivos, como a moralidade e a probidade administrativa, compondo o chamado microssistema processual de tutela coletiva (PAZZAGLINI FILHO, 2018, p 172).

Tal conclusão tem respaldo no art. 129, inciso III da CR/88, que alargou as hipóteses de proteção da Lei de Ação Civil Pública, para alcançar o patrimônio público e social, do

\footnotetext{
${ }^{1}$ Ver Lei 12.850/13 (BRASIL, 2013).

${ }^{2}$ Ver Lei 12.846/13 (BRASIL, 2013).
} 
meio ambiente e de outros interesses difusos e coletivos, estes entendidos como qualquer interesse público ou geral (DI PIETRO, 2019, p 1.761 e 1.830).

Mas o que seria o termo de ajustamento de conduta nas ações de improbidade administrativa?

Poder-se-ia dizer que o termo de ajustamento de conduta seria uma espécie de acordo, com características próprias, de caráter facultativo, logo não obrigatório, mas que se diferencia das transações típicas por inexistir concessões recíprocas das partes para alcançar a solução consensual do conflito (RODRIGUES, 2011, p. 130).

Sem que se renuncie a qualquer direito, os legitimados aos acordos devem ponderar, a partir do caso concreto, qual a melhor solução e de que forma o interesse público estaria sendo preservado (PINHO, 2018). Interesse que, nas ações de improbidade administrativa, conforme já abordado, é a preservação da moralidade e do patrimônio público.

Por isso, ao se admitir a realização do termo de ajustamento de conduta nas hipóteses de improbidade administrativa, não se estaria a beneficiar o agente público ímprobo, mas a buscar a solução mais célere e efetiva para a proteção da moralidade administrativa e a tutela do patrimônio público, por meio do ressarcimento ao erário, promovendo a própria eficiência da Administração Pública.

Seguindo essa diretriz, o Conselho Superior do Ministério Público do Estado de Minas Gerais - CSMPMG também editou a Resolução n. ${ }^{\circ} 03$ de 23 de novembro de 2017 que regulamentou, no âmbito estadual, o compromisso de ajustamento de conduta envolvendo as hipóteses configuradoras de improbidade administrativa, previstas na Lei de Improbidade Administrativa, sem prejuízo do ressarcimento ao erário e da aplicação de uma ou de algumas das sanções previstas na Lei, conforme o caso concreto (MINAS GERAIS, 2017).

$\mathrm{Na}$ oportunidade, ressaltou a necessidade de efetivar os direitos e garantias fundamentais de acesso a uma justiça mais célere e eficiente, através da autocomposição dos conflitos, em contrapartida à crescente judicialização e tradicional resolução dos conflitos pelo Poder Judiciário; apontou os princípios e normas trazidas pelo Código de Processo Civil de 2015 que incorporaram e enalteceram os mecanismos de autocomposição, bem como assinalou a existência de outros instrumentos capazes de afastar as sanções típicas previstas nas Leis, em contrapartida à realização do bem jurídico protegido, como é o caso da colaboração premiada, no campo penal, e do acordo de leniência, no campo administrativo (MINAS GERAIS, 2017). 
Assim, a realização do termo de ajustamento de conduta, consoante estabelecido no art. $3^{\circ}$ da Resolução n..$^{\circ}$ 03/17, de iniciativa do Ministério Público ou do responsável pelos atos de improbidade, pessoa física ou jurídica, tem como objetivo a aplicação mais rápida e eficaz das sanções previstas na Lei de Improbidade Administrativa, contribuindo para prevenir e reprimir as condutas ímprobas.

Como afirmado, não se trata de eximir o Estado do seu dever de persecução e de combate a corrupção, ou de uma benesse dada ao agente ímprobo, já que a celebração do compromisso de ajustamento somente se perfaz com a obrigação firmada de reparar integralmente o dano sofrido; de transferir ou devolver, sem ônus para a entidade lesada, os bens, os direitos ou os valores adquiridos com a infração; de cessar a conduta ilícita; e de oferecer garantias para o pagamento da multa civil, ressarcimento e transferência (MINAS GERAIS, 2017).

E a depender da extensão do dano e do grau de censura da conduta ímproba, o termo de ajustamento de conduta também poderá exigir do agente público o compromisso de pagamento de multa civil; de não contratar com o Poder Público ou receber benefícios ou incentivos fiscais ou creditícios, direta ou indiretamente, ainda que por intermédio de pessoa jurídica da qual seja sócio majoritário, por período determinado; de renunciar à função pública; de reparar os danos morais coletivos; e de renunciar ao direito de candidatar-se a cargos públicos eletivos, por períodos determinados, sempre limitado ao máximo estipulado no art. 12 da Lei de Improbidade Administrativa (MINAS GERAIS, 2017).

Quanto ao momento de celebração dos compromissos de ajustamento de conduta, tanto a Resolução n. ${ }^{\circ}$ 179/17, quanto a Resolução n. ${ }^{\circ}$ 03/17, admitem a celebração do acordo em qualquer fase da investigação, inquérito civil ou processo judicial, desde que assinado pelo representante do Ministério Público e que não implique em renúncia a direito ou interesses difusos ou coletivos e individuais homogêneos (BRASIL, 2017; MINAS GERAIS, 2017).

No caso dos ajustes celebrados durante a ação judicial, exigiu-se como condição de sua eficácia a homologação judicial, também exigida para o caso de aplicação do compromisso de renúncia à capacidade eleitoral passiva. Se realizada durante o inquérito civil ou procedimento preparatório para ação judicial, basta a homologação do Conselho Superior do Ministério Público (MINAS GERAIS, 2017).

Não obstante a regulamentação pelos órgãos ministeriais, fato é que os acordos, ao menos aqueles firmados durante a ação de improbidade administrativa, eram realizados ao 
arrepio da Lei, cuja alteração legislativa ocorreu tão somente com a publicação da Lei n. ${ }^{\circ}$ 13.964/19 - Pacote Anticrime, que trouxe mudanças significativas para o assunto.

\subsection{OS ACORDOS DE NÃO PERSECUÇÃO CIVIL NA LEI DE IMPROBIDADE ADMINISTRATIVA}

A Lei n. ${ }^{\circ}$ 13.964/19, publicada em 24 de dezembro de 2019, além de aperfeiçoar a legislação penal e processual penal, alterou o art. $17, \S 1^{\circ}$ da Lei n. ${ }^{\circ} 8.429 / 92$ para admitir a celebração de acordo de não persecução cível, cuja vigência teve início em 23 de janeiro de 2020 (BRASIL, 2019).

A alteração fez parte do chamado pacote anticrime proposto pelo Ministro da Justiça e Segurança Pública Sérgio Moro e por uma comissão de juristas coordenada pelo ministro do Supremo Tribunal Federal Alexandre de Moraes, parcialmente alterado pelos parlamentares, depois de submetida a diversos debates e que culminou na sanção e publicação da Lei n. ${ }^{\circ}$ 13.964/19, que alterou a redação do art. $17, \S 1^{\circ}$ da Lei de Improbidade Administrativa e acrescentou o $§ 10-\mathrm{A}$, que passou a prever:

\footnotetext{
Art. 17. A ação principal, que terá o rito ordinário, será proposta pelo Ministério Público ou pela pessoa jurídica interessada, dentro de trinta dias da efetivação da medida cautelar.

$\S 1^{\circ}$ As ações de que trata este artigo admitem a celebração de acordo de não persecução cível, nos termos desta Lei.

[...]

$\S 10$-A. Havendo a possibilidade de solução consensual, poderão as partes requerer ao juiz a interrupção do prazo para a contestação, por prazo não superior a 90 (noventa) dias. (BRASIL, 2019).
}

A partir de uma leitura atenta dos dispositivos, bem como das justificativas aos vetos ocorridos em outros parágrafos da Lei, extrai-se, contudo, que a permissão de celebração dos acordos se restringiu ao momento do inquérito civil ou durante o juízo prévio de admissibilidade da petição inicial nas ações de improbidade administrativa. A alteração legislativa não permitiu a celebração de acordos em toda e qualquer fase das ações de improbidade de que trata a Lei n. ${ }^{\circ} 8.429 / 92$.

$\mathrm{O}$ art. 17-A, $\S 2^{\circ}$ da Lei que previa a celebração dos acordos no curso da ação de improbidade foi vetado pelo Presidente da República, não tendo sido derrubado pelo Poder Legislativo. Justificou-se o veto na possível ineficiência dos acordos celebrados em momento 
anterior ao curso da demanda, pois permitiria ao infrator continuar litigando judicialmente e depois, caso desejasse, optar pela transação judicial, deixando de atender aos propósitos do instrumento de resolução consensual de conflito - reparação mais célere e desaforamento do Poder Judiciário (BRASIL, 2019).

Desse modo, resta evidente que a alteração normativa permitiu tão somente a celebração de acordos para a não persecução civil que, como o próprio nome sugere, deve ser realizado em momento anterior ao procedimento principal da ação de improbidade, visando exatamente evitar o desfecho judicial na solução da controvérsia.

Esclareça-se que o procedimento previsto na Lei de Improbidade Administrativa tem caráter especial, com atos próprios e diferentes do rito ordinário tratado no Código de Processo Civil, muito embora o art. 17 da Lei n. ${ }^{\circ}$ 8.429/92 a nomeie como de rito ordinário (CARVALHO FILHO, 2019, p.1.090).

A ação de improbidade administrativa apresenta dois procedimentos distintos e não autônomos: o procedimento de juízo prévio de admissibilidade da demanda e o procedimento principal. No primeiro momento, distribuída a petição inicial, o juízo notificará o requerido para apresentar sua defesa prévia e, ao final, munido das primeiras informações, receberá ou rejeitará a peça de ingresso, seja pela ausência do ato de improbidade, pela improcedência do pedido ou pela inadequação da via eleita. (CARVALHO FILHO, 2019, p. 1.090; PAZZIGLINI FILHO, 2018, p. 174).

Veja que a notificação do requerido para apresentação da defesa prévia constitui um contraditório preambular realizado em fase anterior à citação do réu e, portanto, antes da formação regular da relação processual (CARVALHO FILHO, 2019, p. 1.090; PAZZIGLINI FILHO, 2018, p. 178).

Por isso, os acordos admitidos são aqueles celebrados durante o inquérito civil ou no juízo prévio de admissibilidade da ação de improbidade, mas não durante o procedimento principal. Não se trata, contudo, de qualquer novidade, já que se entendia que a vedação legal anterior se restringia aos acordos realizados durante a ação de improbidade e não durante o inquérito civil (FERRAZ, 2019).

Tanto assim que os membros do Ministério Público já celebravam termos de ajustamento de conduta com os supostos agentes ímprobos, com base na Resolução n. ${ }^{\circ} 179$ do 
CNMP e, no âmbito do Estado de Minas Gerais, com base na Resolução n. ${ }^{\circ} 03$ do $\mathrm{CSMPMG}^{3}$.

Será possível, contudo, afirmar existir consensualidade nos acordos de não persecução cíveis, tal como previsto na Lei n. ${ }^{0}$ 13.964/19, durante o inquérito civil das ações de improbidade administrativa?

\section{CONTROLE CONSENSUAL DA ADMINISTRAÇÃO PÚBLICA NA IMPROBIDADE ADMINISTRATIVA}

O controle da Administração Pública caracteriza-se pela função de fiscalização, orientação e correção exercida pelos poderes, órgãos ou autoridades sobre o exercício funcional uns dos outros - controle externo, ou de um poder, órgão ou autoridade sobre os seus próprios atos - controle interno.

Trata-se do sistema de freios e contrapesos consagrado no Estado Democrático Direito, a partir da teoria da separação de poderes, prevista no art. $2^{\circ}$ da CR/88 (BRASIL, 1988).

Usualmente, a doutrina costuma classificar o controle da administração pública segundo o órgão ou poder que o exerce - administrativo, legislativo ou judiciário; segundo o momento em que ocorre - prévio, concomitante ou posterior ao ato ilegal; segundo o modo interno ou externo; e segundo a atividade ou o aspecto de seu controle - de legalidade ou de mérito (FERRAZ, 2019; DI PIETRO, 2018).

O controle administrativo, especificamente, é aquele exercido pela Administração Pública sobre sua própria atuação por meio da autotutela - de ofício ou mediante recursos administrativos -, enquanto o controle legislativo exercido sobre a Administração se transparece no controle político ou financeiro e o controle judicial mediante as diversas ações judiciais disponíveis aos jurisdicionados para impugnar os atos administrativos (DI PIETRO, 2018).

Segundo Luciano Ferraz, a mudança de paradigma do Estado liberal e do Estado intervencionista para o Estado pós-social ou neoliberal, trouxe transformações na Administração Pública, que passou a utilizar de mecanismos de controle consensual na sua relação com os órgãos e agentes públicos, ao invés do sancionatório, realizado

\footnotetext{
${ }^{3}$ Ver Capítulo 2, item 2.1.
} 
exaustivamente para a punição ou responsabilização do agente. Dessa forma, propõe um novo critério de classificação das espécies de controle, consistente na diferenciação da sua consequência jurídica - controle sancionatório ou consensual (FERRAZ, 2019).

\begin{abstract}
O controle do tipo sancionatório, embora não despareça diante das propostas de modernização da Administração Pública e do direito que lhe é peculiar (direito administrativo), é mais ajustado coma Administração unilateral e monológica que prevaleceu no passado, enquanto o controle consensual aqui proposto é afinado com a Administração concertada e dialógica, fundado no princípio da consensualidade, e utilizável todas as vezes em que não seja essencial se valer dos rasgos de imperatividade típicos de um agir estatal unilateral. (FERRAZ, 2019, p. 135)
\end{abstract}

A inversão da lógica crime-castigo teria como objetivo assumir "contornos de diálogo, na busca da maximização dos objetivos fundamentais e dos fundamentos do Estado democrático de direito. [...] que estimulem transparência, eficiência, economicidade, eficácia e efetividade." (FERRAZ, 2019, p. 168).

A ação de improbidade administrativa seria então um exemplo de controle sancionatório, pois tem o objetivo de responsabilizar e de punir o agente ímprobo, aplicandolhe as sanções severas previstas em Lei, ao passo que o termo de ajustamento de conduta seria o meio de controle consensual a ser utilizado nas improbidades administrativas, afinando-se com uma proposta de Administração Pública mais dialógica e menos autoritária (FERRAZ, 2019).

Ocorre que a celebração do termo de ajustamento de conduta permitida pela Lei de Improbidade Administrativa é aquela realizada durante o inquérito civil ou previamente à propositura de demanda principal, tal como já previa as Resoluções do CNMP e do CSMPMG, fases procedimentais que, em regra, dispensa-se o contraditório e a ampla defesa, afastando-se da consensualidade própria dos acordos.

\title{
3.1 O CONTROLE CONSENSUAL E O INQUÉRITO CIVIL NA IMPROBIDADE ADMINISTRATIVA
}

O inquérito civil é um instrumento de investigação disponível ao Ministério Público para o exercício do seu controle sobre a Administração, função precípua desse órgão, previsto no art. 129, inciso III da CR/88 (BRASIL, 1988) e legislações esparsas, tal como no art. $8^{\circ}, \S^{\circ}$ da Lei n. ${ }^{\circ} 7.347 / 85$ - Lei de Ação Civil Pública (BRASIL, 1985) e regulamentado 
pela Resolução n. 23 do Conselho Nacional do Ministério Público - CNMP (BRASIL, 2007).

Por meio dele, colem-se provas necessárias à fundamentação de uma pretensão ministerial em futura ação civil ou colem-se dados capazes de efetivar as soluções extrajudiciais de conflitos, como a mediação, a conciliação, a transação e a negociação direta (ALVES; ZANETI JÚNIOR, 2016).

Nos termos da Resolução n. ${ }^{\circ} 23$ do CNMP, o procedimento do inquérito civil pode ser instaurado de ofício, em razão de alguma representação ou por designação do Procurador Geral de Justiça e demais autoridades e órgãos superiores, cabendo ao membro do Ministério Público que presidirá o inquérito, instruir o procedimento administrativo, requisitando esclarecimentos e/ou diligências necessárias para a investigação (BRASIL, 2007).

Além disso, estabelece que o defensor público poderá ter acesso às investigações, retirando cópias e fazendo os apontamentos que se fizerem necessários, todavia, delimitado pelo presidente, sempre que puder comprometer a eficiência, eficácia ou finalidade das diligências. Deve ser finalizado dentro de um ano, sujeito a prorrogação por igual prazo e de forma indefinida, pelo tempo necessário à realização das diligências (BRASIL, 2007).

A jurisprudência acrescenta que, como procedimento inquisitivo e informal, dispensa-se o contraditório e a ampla defesa, possuindo suas provas valor probatório relativo (STJ, 2015 $5^{4}$ STF, 2011 ${ }^{5}$ ). Isso porque, sendo um instrumento investigatório sem qualquer caráter punitivo - não aplica sanções -, não alteraria a esfera jurídica do cidadão, que teria a oportunidade de se defender em juízo (ALVES; ZANETI JÚNIOR, 2016).

Ocorre que, conforme exposto, os ajustes realizados pelos membros do Ministério Público, com base nas resoluções do CNMP e CSMPMG, não apenas buscam cessar a irregularidade encontrada, como também impor sanções ao agente público investigado que "aceitou" a celebração do termo de ajustamento de conduta, a partir de provas realizadas exclusivamente pelo Ministério Público durante o inquérito civil. É evidente que, promovendo-se o contraditório e a ampla defesa, "processualizando" os procedimentos,

\footnotetext{
${ }^{4}$ Ver AgRg no AREsp 572.859/RJ, Rel. Ministro Humberto Martins, Segunda Turma, julgado em 18/12/2014 DJe 03/02/2015 (STJ, 2015).

${ }^{5}$ Ver RE 481955 AgR, Rel. Ministra Cármen Lúcia, Primeira Turma, julgado em 10/05/2011, DJe 26/05/2011 (STF, 2011).
} 
aumentam as chances de uma solução verdadeiramente consensual dos conflitos (ALVES; ZANETI JÚNIOR, 2016).

Como se não bastasse, a desnecessidade de homologação judicial, tal como prevista na Resolução n. ${ }^{\circ} 03$ do CSMP de Minas Gerais (MINAS GERAIS, 2017) impossibilita o controle a que deve ser submetido o próprio órgão ministerial, quanto à eventual abuso de poder ou irregularidade na condução do procedimento e da celebração dos acordos.

Assim, seja pela natureza atribuída ao procedimento inquisitivo ou pelo conceito de controle consensual da Administração Pública, dado por Luciano Ferraz (FERRAZ, 2019), não é possível, nesta fase, conceber a celebração do termo de ajustamento de conduta, quando ausente qualquer diálogo entre as partes na construção do provimento final. Não se trata de negar a possibilidade de realização dos acordos, mas tão somente de garantir a realização dos direitos fundamentais dos cidadãos em um Estado Democrático de Direito.

\section{CONCLUSÃO}

A mudança de paradigma do Estado impositivo para o Estado dialógico, gerou reflexos nos instrumentos ou formas de controle da Administração. A tendência hoje é a busca pela solução consensual de conflitos, ao revés do controle meramente repressivo ou impositivo.

Inclusive, a conciliação, a mediação e outros métodos de solução consensual de conflitos, foram reconhecidos como fundamento da nova sistemática processual brasileira, devendo o Estado promovê-las sempre que possível, nos termos do art. $3^{\circ}, \S \S 2^{\circ}$ e $3^{\circ}$ do CPC/15. (BRASIL, 2015).

Nesta perspectiva e considerando a necessidade de uma solução mais célere e eficaz no combate à corrupção, como forma de combater a demora e os elevados custos de um processo judicial, o art. $17, \S 1^{\circ}$ da Lei n. ${ }^{\circ} 8.429 / 92$ foi alterado pela Lei n. ${ }^{\circ} 13.964 / 19$ Pacote Anticrime, para permitir a celebração de acordos de não persecução cível nas ações de improbidade administrativa de que trata a Lei (BRASIL, 2019).

A permissão, contudo, restringe-se à fase inquisitória e preparatória à demanda principal da ação de improbidade administrativa, conforme se extrai da interpretação dada aos 
demais dispositivos alterados e/ou incluídos e das justificativas aos vetos realizados pelo Presidente da República a comandos normativos que compunham o Pacote Anticrime.

Mas como admitir a realização dos termos de ajustamento de conduta durante o inquérito civil nas improbidades administrativas?

Em tese, o objetivo do inquérito civil é coletar as provas necessárias para fundamentar a propositura de uma ação civil pelo Ministério Público. E porque não teria o objetivo de impor qualquer sanção ao acusado, dispensar-se-ia o contraditório e a ampla defesa.

Ocorre que o termo de ajustamento de conduta, enquanto instrumento de controle consensual da Administração Pública, em contraponto ao controle-sanção, quando realizado nas hipóteses de improbidade administrativa, com base nas diretrizes traçadas nas Resoluções n. ${ }^{\circ} 179$ do CNMP e n. ${ }^{\circ} 03$ do CSMPMG, não apenas fazem cessar a ilegalidade impugnada, como também aplicam as demais sanções previstas na Lei (BRASIL, 2017; MINAS GERAIS, 2017), subvertendo a sua função.

Assim, por lhe faltar a dialeticidade própria do controle consensual, não há como admitir a celebração do termo de ajustamento de conduta durante o inquérito civil, quando não garantida a participação do investigado, assegurando-lhe o contraditório e a ampla defesa, direitos fundamentais no Estado Democrático de Direito.

\section{REFERÊNCIAS}

ALVES; Gustavo S.; ZANETI JÚNIOR, Hermes. Inquérito civil, contraditório e improbidade administrativa: Um diagnóstico crítico dos precedentes das cortes supremas Brasileiras.

Revista Eletrônica de Direito Processual. Rio de Janeiro. Ano 10. Volume 17. Número 2. Jul a Dez de 2016.

BRASIL. Conselho Nacional de Justiça. Justiça em Números 2019, Brasília: CNJ, 2019.

BRASIL. Conselho Nacional do Ministério Público. Resolução no 23, de 17 de setembro de 2007. Regulamenta os artigos $6^{\circ}$, inciso VII, e $7^{\circ}$, inciso I, da Lei Complementar $n^{\circ} \mathbf{7 5 / 9 3}$ e os artigos 25, inciso IV, e 26, inciso I, da Lei no 8.625/93, disciplinando, no âmbito do Ministério Público, a instauração e tramitação do inquérito civil. Disponível em: https://www.cnmp.mp.br/portal/images/Resolucoes/Resoluo-0231.pdf. Acesso em: 10 jan 2020 . 
BRASIL. Conselho Nacional do Ministério Público. Resolução $\mathrm{n}^{\circ}$ 179, de 26 de julho de 2017. Regulamenta o $\$ 6^{\circ}$ do $\operatorname{art.~}^{\circ}$ da Lei $n^{\circ} 7.347 / 1985$, disciplinando, no âmbito do Ministério Público, a tomada do compromisso de ajustamento de conduta. Disponível em:http://www.cnmp.mp.br/portal/images/Resolucoes/Resolu\%C3\%A7\%C3\%A3o-179.pdf. Acesso em: 10 jan 2020.

BRASIL. Conselho Nacional do Ministério Público. Resolução ${ }^{\circ}$ 125, de 29 de novembro de 2010. Dispõe sobre a Política Judiciária Nacional de tratamento adequado dos conflitos de interesses no âmbito do Poder Judiciário e dá outras providências. Disponível em: https://atos.cnj.jus.br/atos/detalhar/atos-normativos?documento=156.Acesso em: 10 jan 2020.

BRASIL. Constituição da República Federativa do Brasil de 1988. Disponível em:http://www.planalto.gov.br/ccivil_03/constituicao/constituicao.htm. Acesso em: 19 jan 2020.

BRASIL. Decreto-Lei n. ${ }^{\circ} 4.657$, de 4 de Setembro de 1942. Lei de Introdução às normas do Direito Brasileiro. Disponível em http://www.planalto.gov.br/ccivil_03/decretolei/del4657compilado.htm. Acesso em 19 jul 2019.

BRASIL. Lei 7.347/85, de 24 de julho de 1985. Disciplina a ação civil pública de responsabilidade por danos causados ao meio-ambiente, ao consumidor, a bens e direitos de valor artístico, estético, histórico, turístico e paisagístico (VETADO) e dá outras providências. Disponível em:

http://www.planalto.gov.br/ccivil_03/leis/L7347orig.htm. Acesso em: 27 jan 2020.

BRASIL. Lei 8.429/92, de 02 de junho de 1992. Dispõe sobre as sanções aplicáveis aos agentes públicos nos casos de enriquecimento ilícito no exercício de mandato, cargo, emprego ou função na administração pública direta, indireta ou fundacional e dá outras providências. Disponível em: http://www.planalto.gov.br/ccivil_03/leis/L8429.htm. Acesso em: 26 jan 2020.

BRASIL. Lei n. $^{\circ} 12.846$, de $1^{\circ}$ de agosto de 2013. Dispõe sobre a responsabilização administrativa e civil de pessoas jurídicas pela prática de atos contra a administração pública, nacional ou estrangeira, e dá outras providências. Disponível em: http://www.planalto.gov.br/ccivil_03/_ato2011-2014/2013/lei/112846.htm. Acesso em: 26 jan 2020.

BRASIL. Lei n. ${ }^{\circ} 12.850 / 13$, de 02 de agosto de 2013. Define organização criminosa e dispõe sobre a investigação criminal, os meios de obtenção da prova, infrações penais correlatas e o procedimento criminal; altera o decreto-lei $n^{0} \mathbf{2 . 8 4 8}$, de 7 de dezembro de 1940 (Código Penal); revoga a lei no 9.034, de 3 de maio de 1995; e dá outras providências. Disponível em: http://www.planalto.gov.br/ccivil_03/_ato20112014/2013/lei/112850.htm. Acesso em: 25jan 2020. 
BRASIL. Lei 13.105/15, de 16 de março de 2015. Código de Processo Civil. Disponível em: http://www.planalto.gov.br/ccivil_03/_ato2015-2018/2015/lei/113105.htm. Acesso em: 19 jan 2020.

BRASIL. Lei 13.964, de 24 de dezembro de 2019. Aperfeiçoa a legislação penal e processual penal. Disponível em: http://www.planalto.gov.br/ccivil_03/_ato20192022/2019/lei/L13964.htm\#art20. Acesso em: 25 jan 2020.

BRASIL. Medida provisória n. ${ }^{\circ} 703$, de 18 de dezembro de 2015 . Altera a Lei $\mathbf{n}^{\mathbf{0}} \mathbf{1 2 . 8 4 6}$, de $1^{\circ}$ de agosto de 2013, para dispor sobre acordos de leniência. Disponível em http://www.planalto.gov.br/ccivil_03/_Ato2015-2018/2015/Mpv/mpv703.htm. Acesso em 10 jan 2020.

BRASIL. Ministério da Justiça e Segurança Pública [notícias]. Lei Anticrime entra em vigor: Medidas modernizam legislação no combate à corrupção, organização criminosa e violência. Brasília, 2020. Disponível em: https://www.novo.justica.gov.br/news/lei-anticrimeentra-em-vigor. Acesso em: 25 de jan2020.

BRASIL. Supremo Tribunal Federal. AgR no RE 481955, Rel. Ministra Cármen Lúcia, Primeira Turma, julgado em 10 mai 2011. Publicado em 26 mai 2011. Disponível em: http://redir.stf.jus.br/paginadorpub/paginador.jsp?docTP=AC\&docID=623407. Acesso em 1 fev. 2020.

BRASIL. Superior Tribunal de Justiça. AgRg no AREsp 572.859/RJ, Rel. Ministro Humberto Martins, Segunda Turma, julgado em 18 dez 2014. Publicado em 03 fev 2015. Disponível em https://ww2.stj.jus.br/processo/revista/inteiroteor/?num_registro=201402191226\&dt_publicac ao=03/02/2015. Acesso em 30 mar 2020 .

BRASIL. Presidência da República. Mensagem n 726, de 24 de dezembro de 2019. Brasília, Disponível em: http://www.planalto.gov.br/ccivil_03/_ato20192022/2019/Msg/VEP/VEP-726.htm. Acesso em: 25 de jan2020.

CARVALHO FILHO, José dos Santos. Manual de direito administrativo. 31. ed. rev. atual e ampl. São Paulo: Atlas, 2018.

DI PIETRO, Maria Sylvia Zanella. Direito administrativo. 32. ed. Rio de Janeiro: Forense, 2019. $1932 \mathrm{p}$.

FERRAZ, Luciano. Controle e consensualidade: fundamentos para o controle consensual da Administração Pública (TAG, TAC, SUSPAD, Acordos de leniência, Acordos substitutivos e instrumentos afins). Belo Horizonte: Fórum, 2019. 
MACHADO, Pedro Antônio de Oliveira. Acordo de leniência e a lei de improbidade administrativa. Curitiba: Juruá, 2017. 259 p.

MEDAUAR, Odete. Direito Administrativo Moderno. 21. ed. Belo Horizonte: Fórum, 2018. 444 p.

MINAS GERAIS (Estado). Conselho Superior Do Ministério Público Do Estado De Minas Gerais. Resolução CSMP n. ${ }^{\circ}$ 3, de 23 de novembro de 2017. Regulamenta, no âmbito do Ministério Público do Estado de Minas Gerais, o Compromisso de Ajustamento de Conduta envolvendo hipóteses configuradoras de improbidade administrativa (definidas na Lei n. ${ }^{\circ}$ 8.429, de 2 de junho de 1992). Disponível em https://www.mpmg.mp.br/files/diariooficial/DO-20171129.pdf. Acesso em10 jan 2020.

MOTTA, Reuder Cavalcante. Tutela do patrimônio público e da moralidade administrativa: interpretação e aplicação. Belo Horizonte: Fórum, 2012. 279 p.

OLIVEIRA, Marcelo Henrique Matos. Considerações sobre os direitos transindividuais. Cognitio Juris, João Pessoa, Ano I, Número 2, agosto 2011. Disponível em https://www.cognitiojuris.com/artigos/02/06.html. Acesso em 22 jan 2020.

PAZZAGLINI FILHO, Marino. Lei de improbidade administrativa comentada: aspectos constitucionais, administrativos, civis, criminais, processuais e de responsabilidade fiscal. 7. ed. São Paulo: Editora Atlas, 2018.

PINTO, José Guilherme Bernan Correa. Direito administrativo consensual, acordo de leniência e ação de improbidade. Disponível em:

https://www.bmalaw.com.br/arquivos/Artigos/artigo_ibda_jgb.pdf. Acesso em 27 jan 2020.

RODRIGUES, Geisa de Assis. Ação civil pública e termo de ajustamento de conduta: teoria e prática. 3. ed. Rio de Janeiro: Forense, 2011. 